\title{
ヘアーラッカー粘結剤の高温・高湿下の性質
}

\section{The properties of the hair spray resins.}

\author{
三上 正 勝
}

Masakatsu MIKAMI

\begin{abstract}
Experiments are conducted to obtain the comparative performance data at high temperature and humidity on some commercial hair spray resins. The quantitative evaluation of the hair-setting ability of the resin was made by "Curl Retention Test", whareas the stickiness of the resin was meaured by using a Sward Rocker Hardness Meter. It was found that the test results were affected by the type of the resin as well as the kind of the neutralizer used.
\end{abstract}

\section{1. 緒言}

今日までに，ヘアーラッカーの粘結性成分として，そ れぞれ特徴をもった多くの天然，あるいは合成樹脂が開 発され実用されるに抢よんできたが，それらの性質を適 確にとらえてその特徴を明らかにした報告は少なく，乙 たがって, 粘結剤の性質の判定は経験的な触感による方 法，特よびモニターなどによる使用テストが主たる手段 となっているため, 素材の不均一さ, 試験の煩雑さ, 条 件設定のむづかしさ，などの点で研究活動のら党で大き な支障となっている。一方整髪剤の分野に拈いて大きな 役割を占めるへアーラッカーは，午の理想とする性状， すなわち, 自然なセットの仕上がりやセットしたカール の保持力の持続性, とくに高温・高湿下での挙動を, そ の性能の中で求める傾向にある。

われわれは，へアーラッカーの粘結性樹脂成分とし て, ビニル系単量体, なかでも变性アクリル系樹脂の応 用開発に従事してきたが，その際に行なった性能試験の 方法である，カールリテンション怙よびスオードロッカ 一テストの内容と結果について，ここに報告する。

\section{2. 実験および結果}

本報告に述べるテストは，いずれもェアゾールとした ものを試料とし，また入手した比較対象とする市販エア ゾールに関しては, 実験の均一性を期するため, エアデ 一ルから同一のバルブを有するェアゾール缶へ, 内容物 を移したものを試料として用いた。またわれわれが開発

京都府宇治市伊勢田町井尻58

互応化学工業(株) 研究部
Table-1 武作樹脂によるエアゾール姏方

\begin{tabular}{|c|c|c|c|c|}
\hline 原 料 試 料 & $53 \mathrm{~A}-1$ & $53 \mathrm{~A}-2$ & $53 \mathrm{~B}-1$ & $53 \mathrm{~B}-2$ \\
\hline 試作 Resin $53 \mathrm{~A}$ & $3.0 \%$ & $4.0 \%$ & & \\
\hline $53 \mathrm{~B}$ & & & $3.0 \%$ & $4.0 \%$ \\
\hline 香 & 0.3 & 0.3 & 0.3 & 0.3 \\
\hline 無水エタノール & 96.7 & 95.7 & 96.7 & 95.7 \\
\hline フロンF11/F12の組成 & $50 / 50$ & $50 / 50$ & $50 / 50$ & $50 / 50$ \\
\hline 原液／ガスの割合 & $40 / 60$ & $40 / 60$ & $40 / 60$ & $40 / 60$ \\
\hline
\end{tabular}

したアクリル系樹脂に関しては, Tahe-1のようなェアゾ ールを作成し試料とした。

なお，試作のエアゾール処方に述べているアクリル系 樹脂は, Fig. 1 のような構造を持ち, 53A の場合は存在 するカルボキシル基を2-アミノ-2-メチル-1-プロパノー ル (AMP) にて, 53Bの場合は2-アミノー2-メチル-1・ 3-プロパンジオール (AMPD) にて中和したものであ る。

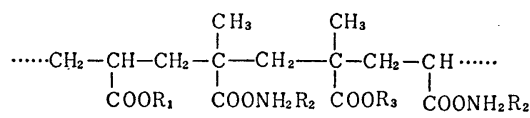

$\mathrm{R}_{1}, \mathrm{R}_{3}: \mathrm{C}_{1 \sim 1}$ の直銷の脂肪族アルコール

$\mathrm{R}_{2}: 2$-メチル-1-プロパノール或いは 2-メチル-1・3-プロパンジオール

Fig.ー1 アクリル系樹脂の構造

$2 \cdot 1$ カールリテンションテスト ${ }^{1,2)}$

$2 \cdot 1 \cdot 1$ 試験方法

パーマネントなどの毛髪に対する処理の未経験の女性 の毛髪で, くせのない部分の長さが約 $23 \mathrm{~cm}$ のものを, 約 $2 \mathrm{~g}$ 分束ねて試験用毛髪 (試験片) とする。つぎに, その試験片をよくシャンプーし, 蒸留水にてすすぎ風乾 しておく。試験片の下端に10gのクリップをとりつけて 
スプレーしたとき，試験片がとび散らないようとして， 毎分30回転するモーターに接続する。そして試験片を回 転させながら，約 $15 \mathrm{~cm}$ の距離から試料エアゾールを 10 秒間スプレーし，直ちに指で付着した液滴をならして， 直径 $1.2 \mathrm{~cm}$ の樹脂製ロッドに巻きクリップする。これ を55〜 60 そて30分間乾燥し，デシケーターに入れて冷 やしてから, Fig.一2のごとく，ら線状に烓どいて，垂直 に立てたガラス板 $(0.5 \mathrm{~cm}$ 毎に目盛をほどこしたもの) 飞取り付け，38〜 40 $\mathrm{C} 95 \%$ RH に調湿した部屋に放置し て，30分間隔で試験片の毛先の位置を10時間にわたって 記録する。なお，カールリテンション值は次の式化て計 算する。

$$
\text { カールリテンション值 }(\%)=\frac{L-L_{t}}{L-L_{0}} \times 100
$$

$L$ ：試験片を十分に伸ばしたときの長さ（ $L=23 ） 。$ $L_{0}$ : 試験片を調湿条件のもとに拉く前のカール先端の 位置。

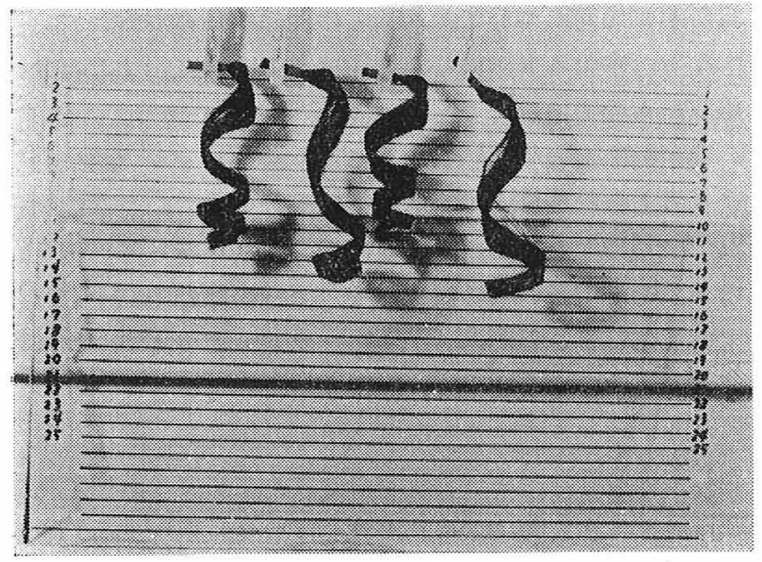

Fig.-2 カールした試験片を測定用ガラス板に取り けたときの状態

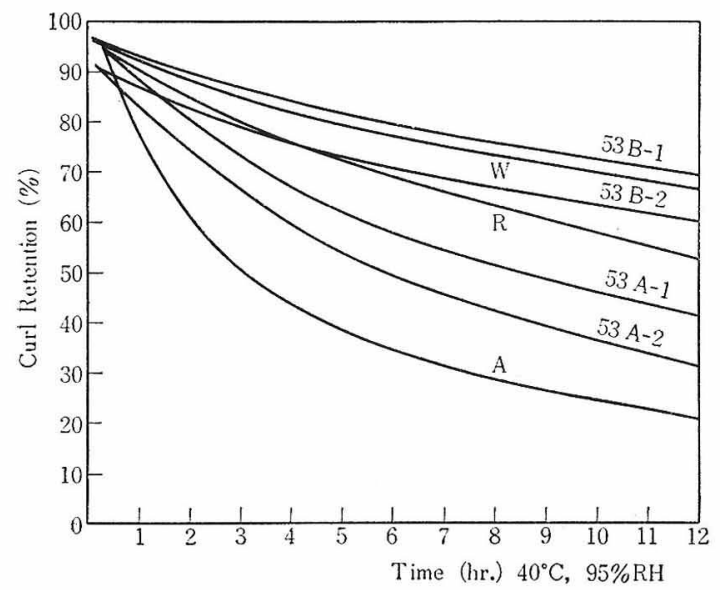

Fig. -2 高湿潤時のカールリテンション
$L_{t}:$ 調湿条件のもとに一定時間放置されたとさのカー ル先端の位置。

ヘアースプレー A， R，W はいずれも米国製品であ り, 53A-1, 53A-2, 53B-1, 53B-2は先ほどのTable1 の内容を持つものである。この実験に際して, スプレ 一された樹脂粘結剤の毛髮に対する付着量を確かめるた ぬに，試験片を $60^{\circ} \mathrm{C}$ に保った乾燥器に 2 時間乾燥後, デ シッーターに入れ，24時間経過したものを試料として， カールリテンションの試料のつくり方に準じて樹脂分を 付着, 次の式にて, 付着率を求めた。

付着率 $(\%)$

$=\frac{\text { 付着後の試験片の重量 }(\mathrm{g}) \text {-試験片の重量 }(\mathrm{g})}{\text { 試験片の重量 }(\mathrm{g})}$ $\times 100$

この結果, 付着率は53A-1, 53B-1, W, R, Aから 噴霧される量としては約 $2.5 \%(0.05 \mathrm{~g})$ であり, $53 \mathrm{~A}$ $-2,53 \mathrm{~B}-2$ は約 $1.8 \%(0.036 \mathrm{~g})$ となる。

Wはカールリテンションで, 高温・高湿環境のもと で，強いカール保持力を維持しているが，この中に含ま れている樹脂成分が形成するフイルムの水溶性は，棌之 んどなく、シャンプーによる洗髪後も，完全に脱落しな いるのである。われわれは，試料へアースプレーとし て，米国産の 7 品種について試験を行なったが，Fig. 3 に示したW， R，A\&現代のヘアースプレーの傾向を端 的に物語っている。すなわち，Wは非常に耐湿性の強い もので，他方では洗髪あるいはこれに基ずくフィーリン グを軽視したものでヘアースプレー粘結郕として，漸新 的な要素を抱合したものであり，Rは現在主流となって いるセット力の強い耐湿性にめぐまれたカールを与光， 十分洗髪性をるったものでフィーリング的にもすぐれた もの，Aはやや性能的にとり残されつつあるものなどで ある。

$2 \cdot 2$ スオードロッカーテスト ${ }^{3,5)}$

$2 \cdot 2 \cdot 1$ 試験方法

水平に保ったミガキ板ガラスの上に, Table-1 のエア ゾール招よび市場より入手した試験用エアゾールを均一 に表面に凹凹が生じないように噴霧して，風などで表面 がなめらかさを失なわないように注意深く保ら，30分間 自然乾燥する。その後, $60^{\circ} \mathrm{C}$ 亿 30 分間乾燥器中で乾燥 してから， $20^{\circ} \mathrm{C} \cdot 65 \% \mathrm{RH}, 23^{\circ} \mathrm{C} \cdot 90 \% \mathrm{RH}, 60^{\circ} \mathrm{C}$ の条件 下で，JIS K-5400に準じてスオードロッカーを用いて測 定する。

\section{$2 \cdot 2 \cdot 2$ 結 果}

な物，スオードロッカー值は，標準ミガキ板ガラス板 そて50となるよう調整したるのである。 
Table-2 スオードロッカー值

\begin{tabular}{|c|c|c|c|}
\hline \multirow{2}{*}{ 試 } & \multicolumn{3}{|c|}{ 件 } \\
\hline & $20^{\circ} \mathrm{C}, 65 \% \mathrm{RH}$ & $23^{\circ} \mathrm{C}, 90 \% \mathrm{RH}$ & $60^{\circ} \mathrm{C}$ \\
\hline $\mathrm{R}$ & 4 & 4 & 3 \\
\hline A & 14 & 2 & 6 \\
\hline W & 12 & 11 & 10 \\
\hline $\mathrm{S}$ (Unscent) & 25 & 21 & 20 \\
\hline S (Extra Hold) & 7 & 3 & 7 \\
\hline $\mathrm{V}$ (Hard) & 24 & 9 & 17 \\
\hline V (Hard-to-Hold) & 25 & 12 & 18 \\
\hline A-1 (Hard) & 23 & 14 & 16 \\
\hline A-2 (Super Hard) & 24 & 16 & 20 \\
\hline B-1 (Standard) & 16 & 5 & 5 \\
\hline B-2 (Strong) & 18 & 16 & 20 \\
\hline $53 \mathrm{~A}-1$ & 24 & 17 & 20 \\
\hline $53 \mathrm{~A}-1$ & 25 & 19 & 21 \\
\hline $53 \mathrm{~B}-2$ & 25 & 17 & 21 \\
\hline $53 \mathrm{~B}-2$ & 25 & 19 & 21 \\
\hline
\end{tabular}

本試験において表われた結果が示す樹脂の性質は，フ イルムの硬さ, 粘着性, みかけの乾燥性, 吸湿性, フィ ルムの連続性（フイルムの均一透明性につながる）添加 剂の影響などが混合されたものと考えられる。したがっ て, $20^{\circ} \mathrm{C} \cdot 65 \% \mathrm{RH}$ のよらな条件で高い值を示しても, 温度や湿度が上昇すると極端に值が低下するものがあ り，旧来のヘアースプレー粘結剤として開発された樹脂 のなかにはこの傾向が著るしい。このことは粘結剤が形 成するフィルムが連続しない脆弱なるのである場合, あ るいは樹脂を構成する単量体の吸湿性が大きい場合が原 因している。また，Table-1 に示した試作の樹脂および 市場のものの 2 - 3 品種の樹脂が高温・高湿での強い性 質を示しているが，これらに共通する点については総括 の項で述べることとする。さらに添加荗との関連性につ いても検討したが，その種類により可塑性を増やし粘着 性につながる傾向にあるものや，各条件下に㧅いて低い 值を示すもの，すなわち耐湿性を向上させるものも見受 けられこれらを応用することによって，ヘアースプレー の性能をある点まで改良することはできるが，この件に 関しては主題と異なるので，別の機会に報告したい。

\section{3. 考察}

近年のヘアースプレーの傾向として, Humidity Proof Wind Proof, Hard to Hold without stiffness といった ことがいわれているが，このたびの実験において，樹脂 の性質およびへアースプレーの処方に，このよらな意図 を持ったものが多く見られる。われわれが行なった実験 の結果から考えると, 樹脂フイルムの硬さとセットの硬 さとは必ずしも質(毛髪の表面での拡がり具合い), 添加

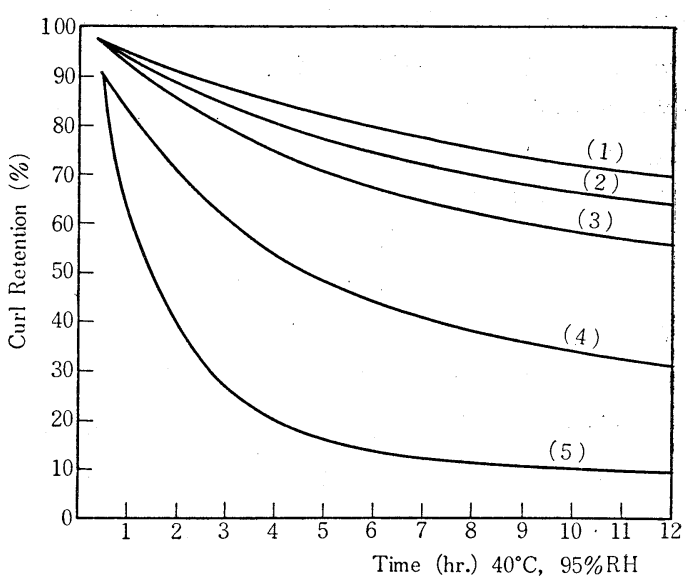

Fig. 一4 高温高湿時のカールリテンション 剂, エアゾール製品の組成などによって，フレーキング 性の減少，ごわごわした不自然さの改善，粘着性の低下 が可能となる。それでは今回の実験に打いて，樹脂の本 質が示す傾向について，構造との関係から述べる。

なお，本テストに供した樹脂は Table-3に示すごとき 組成のものである。

Table-3 と表中の物質のカールリテンション（Fig-4） より考えられることは, その構成成分の中に，塩基性物 質で中和できるフリーなカルボキシル基を持っているも のが，そうでないものに比べて，カール保持力にすぐれ ているということである。また, フリーのカルボキシル 基一を有するものの中で，(1)は共重合しているアクリル 酸あるいはメタアクリル酸エステルの親油基, (2)は共重 合しているビニルエーテル特よびカルポキシル基のアル キルエステル化物，(3)は共重合しているビニルエステル 基, (4)は共重しているビニルピロリドンおよびビニルエ ステル基といったように組合わされているカルボキシル

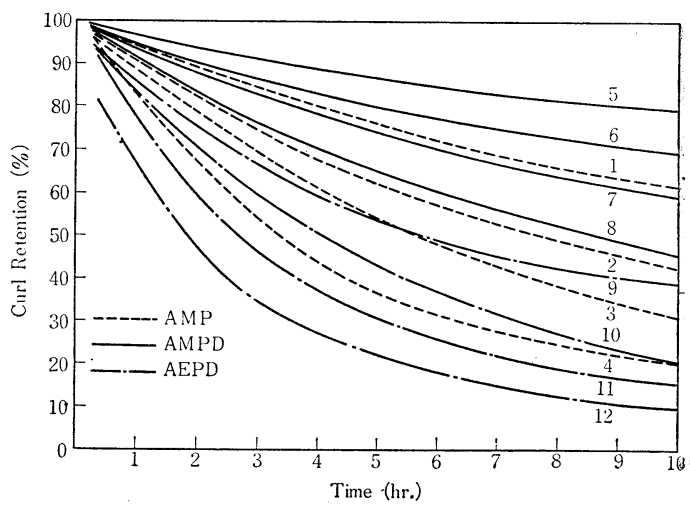

Fig.一5 中和剤扎よび中和率によるカールリテン ションの変化 
Table-3 樹脂の構造別分類

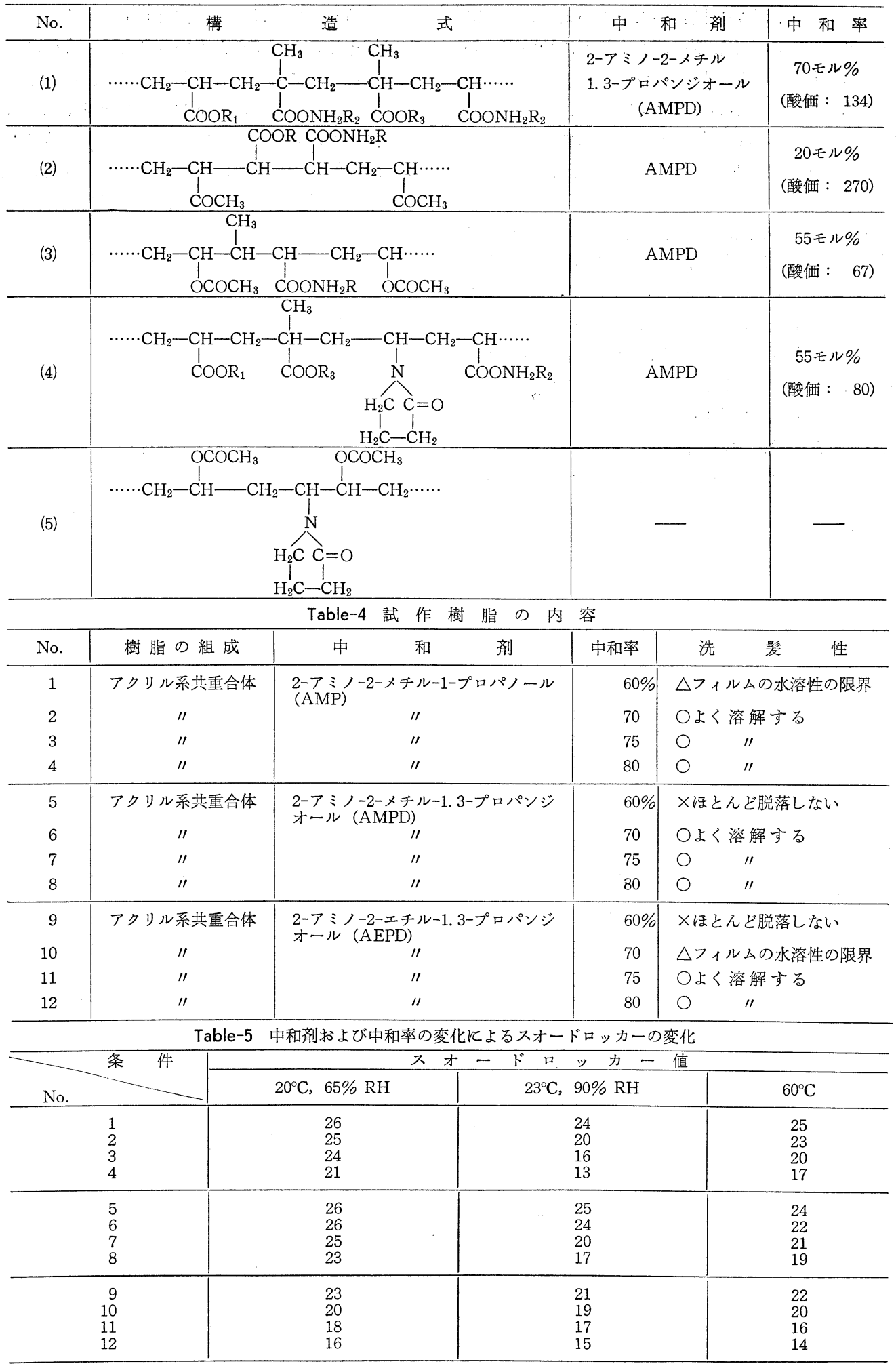


基以外の単量体の蹯水性を比べてみると，その差が樹脂 フィルムの耐湿性に大いに関係があるといえる。つぎに もら一つの要素である中和肪の差と中和率について, わ れわれが試作した樹脂について述べる。実験に用いた樹 脂の内容はTable-4 に示したごとくである。

また，Table-4 に示した組成の樹脂が示すカールリテ ンションおよびスオードロッカーは Fig. -5 , Table-5 K 示す。

中和剤や中和率の関係は, 樹脂の構成モノマーの親水 性に関わることは前に述べたが，一方，中和剂の分子 量, 融点, 塩基としての解離度 (これは吸湿性に影響が ある)なども，Fig. -5, Table-5 より大いに考慮する必 要がある。たとえば, AEPDなどはその分子量の大きさ と低い融点を持つがゆえに, 樹脂に可塑性を与兄, 粘着 性も他の中和剂に比して多いものになる。

今回行なった実験に叔いて得られた結果が，ヘアーラ ッカー粘結剤の性質を決めるすべてとは思われないが,
カール保持カ, オール・ウエザー型のヘアースプレーを 開発するらえに和ける確認法として, その傾向を数值と して捕えることができたといらことは，今後，大いに役 立つところむあろらかと考觉る。高温, 高湿下でのカー ルの硬さについては, ストレーンゲージや回転式硬軟度 比較計などにより，さらに広沉な試験をすることによっ て, 経験的な判断から, 資料による性能分析が可能にな ると思われる。(昭和 47 年 2 月 2 日受理)

\section{参考文献}

1) J. Grande, Drug and Cosmetic Industry 107 (12) 58 (1969)

2) A. L. Micchelli and F. T. Koehler, J. Soc., Cosm, Chemists 19, 863 (Dec. 9.' 1968)

3) J. P. 575,899 (1970)

4) U. S. P. 3, 577, 517 (1971)

5) JIS K-5400 